\title{
HERITAGE SURVEY AND SCIENTIFIC ANALYSIS OF THE WATCHTOWERS THAT DEFENDED THE LAST ISLAMIC KINGDOM IN THE IBERIAN PENINSULA (THIRTEEN TO FIFETEENTH CENTURY)
}

\author{
L. J. García-Pulido ${ }^{\text {a }}$ J. Ruiz Jaramillo a, Mª I. Alba Dorado ${ }^{\text {a }}$ \\ ${ }^{a}$ Dept. of Art and Architecture. High School of Architecture of the University of Malaga, The International \\ Campus of Excellence Andalucía TECH, Spain \\ luis.garcia@uma.es, jonaruizjara@uma.es,maribelalba@uma.es
}

KEY WORDS: New technologies applied to the Heritage documentation, Medieval military architecture, Dissemination and restoration, The Islamic Nasrid Kingdom of Granada, Watchtowers and defensive towers.

\begin{abstract}
:
The Islamic Nasrid kingdom of Granada occupied the mountainous areas of the southeastern area of the Iberian Peninsula. There, a natural border was established between the Nasrid kingdom and the Christian kingdom of Castile from 1232 to 1492 . To control this frontier and establish visual communication between it and the Nasrid center at the Alhambra citadel, an extensive network of watchtowers and defensive towers was constructed.
\end{abstract}

Studies have been done of individual towers, but no comparative study has been undertaken of all of them. Graphic, homogenous, and exhaustively planimetric documentation would bring together existing information on the majority of them and enable comparative analysis. For this reason, this work conducts systematic architectural surveys of all these military structures, using photogrammetry.

In addition to studying the construction typology and techniques, the structural capacity of these towers has been analyzed. It examines how they have been affected by human and natural destructive forces, especially earthquakes, which are common in eastern Andalusia. Although all the historical military architecture is protected by the Spanish and Andalusian Heritage laws, many of these medieval towers and their cultural landscapes are in severe risk.

The towers are being studied as individual specimens (emphasizing their differences) and as a unit in a typological group (looking for similarities and unifying characteristics). New technologies for Information and Communication are being used in order to disseminate the results among specialists and to make them available to the general public. Guidelines for restoration projects are also being formulated from the cases analyzed.

\section{INTRODUCTION}

Given their historical condition as a frontier of kingdoms and civilizations - Islamic and Christian in medieval Iberia - these towers are located in unique sites; being erected as reference landmarks of the territories on which they stand. These fortifications, with very diverse typology and morphology, are a faithful testimony to the different territorial structure that has taken place throughout history (Acién Almansa, 1995; Argüelles Márquez, 1995; Arié, 1992; Malpica Cuello, 1996; Tembory Álvarez, 1985; Terrasse, 1954).

That means that they cannot be understood outside of this territorial dimension. As a result, we find some buildings of invaluable heritage and landscape value. However, the circumstances that have led to the richness of this heritage are those that, at the same time, generate the main problems for their protection. Identifying these Heritage places and their systematic digitizing will allow a better knowledge and their needs to be preserved, keeping their memory for posterity as most of them are in risk.

We can distinguish between two functional types of these military constructions (Martín García et al., 1999):
-The towers next to the no-man's-land between these two kingdoms that controlled roads and natural paths where military raids could be carried out. Although there was no physical connection among them, the closest watchtowers were visually interconnected. In this way encoded information could be transferred from this first defensive line to other towers inside the Nasrid territory, and from there to the main centres.

-These rear-guard border towers provided communication between the towers at the frontline and the intermediate fortresses and the main citadels, often creating a radial web. All of them were placed on hilltops for optimal visibility, at average distances between 5 and $7 \mathrm{~km}$. Thus, the information gathered first-hand at the border could quickly be transmitted to the Alhambra in the Nasrid capital, Granada. In addition to this primary network, in that period there were secondary webs that fulfilled the same function for a given locality. Among them, we should highlight the farmstead towers, usually serving as the main stronghold of a small walled enclosure in order to protect farmers and cattle. The Castilians called them 'cortijos' (from Latin, cohors-cohortis, enclosure or corral).

It is possible to divide the Nasrid border territory into several sectors. During the War of Granada (1482-1491) each strategic city that was conquered by the Catholic Kings (Isabella I of 
Castile and Ferdinand II of Aragon) maintained the control of a large territory surrounding it (Fig. 1).

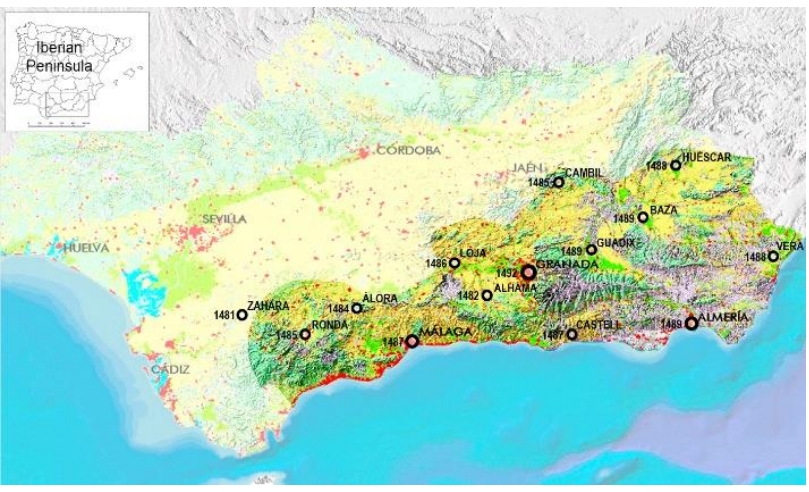

Figure 1. Main cities of the Nasrid kingdom that were sieged and conquered by the Christians during the War of Granada

\section{OBJECTIVES}

The aim of this research is not only an exhaustive knowledge of the typology, morphology, construction, material, landscape, and territory of these medieval military buildings, but also to determine their real state of preservation. It would establish a methodology for their study, restoration and dissemination, in order to protect these elements and their environments. All this will be developed by fostering interdisciplinary approaches in all the phases of study and knowledge of these goods and their territory.

Thus, the location of a large part of these assets far from current urban centres -in mountainous areas that are not easily accessible - means that they are frequently affected by abandonment, neglect, and plunder... So the progressive deterioration of many of these constructions brings many of them to a state close to ruin.

The detailed general objectives of this research project are the following ones:

1. Comprehensive knowledge of the military buildings under study through the preparation of a complete graphical, mapping and cartographic inventory, as well as the study of this extensive heritage from an historical, structural, archaeological, geotechnical, and landscape point of view.

2. Study of the construction techniques in masonry and rammed earth of these military buildings, as well as their evolution in the transition from the Middle Ages to the Modern Period.

3. Analysis of the criteria of implantation of this type of military architecture in the Nasrid kingdom.

4. Establish the relationship between the typologies and morphologies of these buildings as well as with other existing examples on the other side of the border constructed or reused by the Castilians - in order to establish common points and divergences.

5. Study of the characteristics that define the Cultural Landscapes in which these fortifications are situated and which they characterize.
6. Understanding the processes of degradation of these structures over time, analysing their real and current state of conservation. Proposal of the measures necessary to ensure their survival and their legacy for future generations based on this diagnosis.

7. Proposal of a work methodology that aims to establish measures, priorities for action, and intervention criteria. To generate a protocol to work on these assets and their landscapes, fulfilling the requirements formulated by the Spanish and Andalusian Historical Heritage Laws, ensuring at the same time that this complies with the established requirements by the Spanish Technical Building Code (CTE).

8. To define lines of diffusion of this important heritage from the generation of a database of heritage management through Geographic Information Systems instruments for the fortresses under study, so that this information is available in Open Data for researchers as well as for any other interested person.

Among the specific objectives, we can highlight:

1. Photogrammetric surveys of the existing remains linked to these fortifications.

2. Topographical surveys of these military buildings, their enclosures and surroundings, by means of topographical points taken by Total Station. The ground point cloud will be completed with that obtained from the photo-modelling of the terrestrial and aerial photo bundles. From them will a threedimensional model of these fortifications and a threedimensional orography of its surroundings will be made with contour lines at 1:10 scale. Therefore, traditional techniques will be combined with the use of advanced technology such as 3D scanning of the territory using drones (Fig. 2).

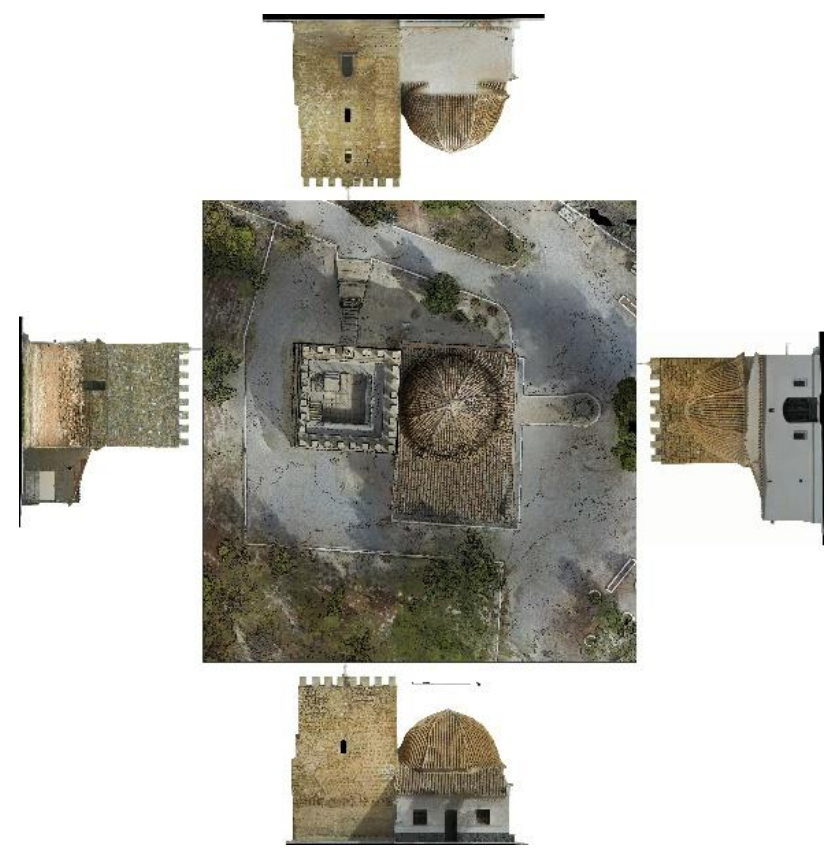

Figure 2. Photogrammetric survey of the medieval Tower of the Ancestors (Torre del Alabi) and the eighteenth century chapel attached to it in Cúllar (Province of Granada, Spain) 
3. Study of the exact chronology of the most representative military buildings of each typology. In addition to establishing comparisons of the masonry and rammed earth construction technology, its typology and modulation, samples are being taken for carbon-14 dating in order to establish their exact ascription. These samples are being analyzed at the Spanish National Centre of Accelerators (Centro Nacional de Aceleradores, CNA. Parque Científico y Tecnológico Cartuja, Seville).

It cannot be forgotten that the use of these techniques of absolute dating can never replace the rigorous and systematic architectural and archaeological analysis of the building. The radiocarbon dating does not make sense without the understanding of the stratigraphic sequence of these architectural remains and if the analysed sample has been obtained in the original context or as a secondary deposition. Therefore, it cannot be used as a shortcut, so as not to jeopardise the full understanding of its construction history.

4. The stratigraphic study of the walls will be undertaken as a whole after mapping these structures.

5. Archaeological survey of the surroundings of these fortifications where scattered surface pottery is preserved. Permission is being sought from the Andalusian Government to analyze and catalogue the existing files on surveys and excavations in several fortifications, stored in the Cultural Delegations of the provinces of Granada, Málaga, Almería, Jaén, and Cádiz.

6. Drawings, perspectives, and 3D-models production in order to disseminate this knowledge in papers, cultural activities, and exhibitions. Animated models that can be disseminated on websites, DVDs or in interpretation centres. This project has an agreement with the Andalusian Institute of Historical Heritage (Instituto Andaluz de Patrimonio Histórico) from the Andalusian Government for the online dissemination of the results and conclusions.

7. Geo-referencing of these fortifications through cartographic database processed by means of GIS applications that facilitate the integration, analysis, and access to the information.

8. Development of patents for projects of documentation and intervention in these fortifications. Furthermore, the conclusions of the research and restoration techniques would be extrapolated to other similar examples. A 'Good practices manual for the recovery of medieval rammed earth and masonry defensive constructions' will be produced.

9. Non-destructive tests that allow the characterization of the ground on which the fortifications have their foundations.

10. Structural parameterization of materials and construction elements of these military buildings, defining the modules of longitudinal and transversal elasticity as well as the Poisson coefficient for both the materials and the resistant elements of the fortifications. Non-destructive testing or minor destructive testing techniques will be used in order not to affect to these cultural assets but to portray them adequately.

All the information obtained will allow the creation of a database for future interventions of consolidation or restoration.

11. From the architectural surveys of the fortifications and the material characterization data, models of finite elements calculation will be elaborated, in order to understand the strengths and weaknesses of these structures. Their rigidity will be studied, especially in regard to horizontal effects (seismic and even the result of war), diagnosing their probable causes of failure. The results obtained will allow the proposal of specific solutions of structural reinforcement adapted to the typology, which should be taken into account in the subsequent restoration projects.

12. Elaboration of a protocol and methodological criteria of intervention for the different typologies of fortifications and their environments. These will refer both to the necessary previous studies, with a view to an adequate and rigorous knowledge of these defensive elements and their landscape, as well as to the definition of procedures and actions that try to preserve and evaluate this Heritage from the point of view of its integral consideration as a Cultural Landscape. Regarding the intervention criteria, the aim will be to facilitate verification of compliance with the regulatory requirements established by the Spanish Technical Building Code (CTE), both by the agents involved and by the respective competent administration.

13. This transcends the mere interpretation as to the scope of the intervention established in the corresponding national and regional legislation on historical heritage. Excluding those actions focused specifically on the consolidation of the property, this study is especially relevant as regards compliance and verification of the basic documents (documentos básicos, $D B$ ) structural safety (seguridad estructural, $S E$ ), safety in case of fire (seguridad en caso de incendio, $S I$ ), health protection against humidity (protección contra la humedad, $H S-1$ ), safety of use (seguridad de utilización, $\mathrm{SU}$ ), and protection against noise (protección contra el ruido, $\mathrm{RH}$ ). Because of clear incompatibility, the corresponding document of energy saving (ahorro de energia, $\mathrm{HE}$ ) as set out in the proposal 'Application of CTE to the works of architectural restoration' reviewed by the Spanish Ministerio de Vivienda, is currently exempt from compliance.

14. Dissemination programs that promote the knowledge and proper interpretation of this heritage will open the access of the public to it through the creation of itineraries, facilitating, in the cases where it is possible and safe, access and visits by the public. Participation and organization of conferences and scientific meetings, through the publications and the application of the Information and Communication 
Technologies, are among other measures. I will attend national and international scientific conferences held annually, such as those organized by the Spanish Society of Construction, Restoration of historic buildings (ResTapia, ReUso, ReHab), conferences of the Earth Group of the University of Valladolid, Archeology of the Conflict and Fortress Group in the United Kingdom...

\section{METHODOLOGY}

The work methodology proposed to carry out this research contemplates different phases focused to the documentation, conservation, and diffusion of these Assets of Cultural Interest.

The aim of this research project is not only to gain an exhaustive knowledge of these towers from different points of view (typological, morphological, construction, material, landscape, territorial...), but also to determine their real state of preservation. Its goal is to establish a methodology for their study, restoration, and dissemination in order to protect these elements and their environments. All of this is being developed by fostering interdisciplinary approaches in all the phases of study and knowledge of these goods and their territory.

The systematic mapping of these military constructions entails the following processes:

Selection of more relevant case studies. It is possible to divide the Nasrid border territory into several sectors where we have made the following selection of watchtowers that preserve a representative part of their elevation (Fig. 3).

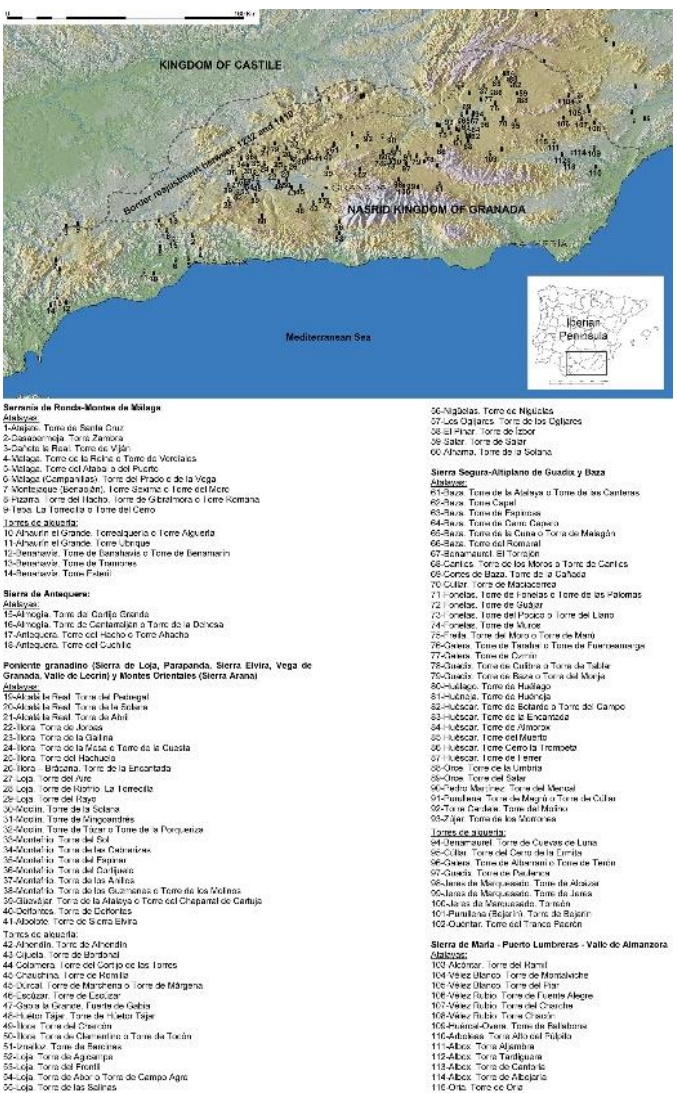

Figure 3. Best preserved Nasrid towers in southeaster Spain
1. Standardization of existing plans and maps.

2. Generation of new graphic documents from specific surveys of each case study.

3. Reconstructive hypothesis where changes have occurred from the architectural and archaeological data obtained from the reading of these buildings as though they were documents themselves.

4. Generation of volumetrics from these data graphics and virtual modelling, especially those kept at an archaeological level.

5. Study of the different construction patterns.

The workflow phases behave the following sections:

6. Data collection and study of historical documentation. This includes an exhaustive search of the textual and graphic documentation related to these military structures:

a) Edited and unedited sources. An extensive bibliographic search of published works and unedited documents is being carried out.

b) Archaeological excavations through the scientific reports gathered at the Provincial Delegations of the Department of Culture from the Government of Andalusia and other publications.

c) Non-metric graphic representations. Analysis of the engravings, drawings, sketches, and environmental perspectives in which these towers appear.

d) Metric graphic representations. The cartographies and aerial photographies preserved in different Archives and Institutes from Andalusia and Spain contain valuable information, since they show the territory before the great urban expansion experienced since the 1960s.

e) Collection of data in situ. A thorough investigation and analysis of data is being carried out regarding the most significant elements of these watchtowers, with the photogrammetric and topographic survey of them and their surroundings. The archaeologists from the team will carry out the necessary surveys to complete the information.

The photogrammetric surveys of these towers are being measured with total station, as well as with laser distance-meters. The terrestrial stereoscopic photographs are being taken by means of a camera of 22 Megapixeles and a lens with focal points of 14, 20 and $28 \mathrm{~mm}$, accompanied by orthogonal and oblique aerial photographs taken with a multi-camera remote control with compact camera of 12 Megapixeles and fixed focal length equivalent to $28 \mathrm{~mm}$. For the restitution and processing of the information a computer with $32 \mathrm{Mb}$ of RAM is being used. We are using software licenses for photographic rectification (ASRix), PoivilliersF for stereo photogrammetry, Orthoware for bundle adjustment and Photoscan for photogrammetric and photomodeling scanning.

f) Structural and material characterization tests. -Extraction of samples of materials and mortars to carry out laboratory identification tests.

-Analysis of the characteristic resistance of the walls and their structural rigidity by means of non-destructive tests: sclerometer, inspection with infrared techniques (thermal camera) or dynamic tests from environmental vibrations. 
-Measurement of deformations and collapses in walls as well as lifting of existing damages, such as cracks, dampness, or weathering of components in the walls.

7. Analysis and interpretation, highlighting relevant aspects obtained in the research. Elaboration of cartographic documentation at different scales (thematic maps, digital terrain models...).

8. Processing the information collected in the previous phase.

a) The treatment of this information in GIS systems allows the systematization and correction of data, introducing factors of rationality and normalization in the information collected, thus facilitating the integration, analysis and consultation of information.

b) Analysis of data taken in situ. In this phase we give special attention to the territorial recognition and analysis of the towers as elements inserted in the territory to which they belong and characterize. This analysis is being developed from a general vision of the territory to a more individual study of each defensive element.

c) Interpretation of the evolution of these towers. Hypothesis will be made of the evolution of its typology from the founding stage to the state of conservation in which they have reached now. It will analyze the transformations undergone by them, their partial destruction, and assimilation by other later constructions. It allows us to identify the basic elements such as repairs or changes in construction techniques.

d) Preserved remains of the defensive systems associated to each tower. Hypothesis about missing elements, with different levels of approximation to reality.

f) Elaboration of calculation models by finite elements. Based on the in situ tests and their resistance and stability against both static and dynamic actions, using probabilistic methods and earthquake data from the historical records.

g) Treatment of information generated at Open Data Source level, so that it is available through different specialization filters (general public, researchers), using free access platforms such as map viewers that currently manage institutions such as the Andalusian Institute of Historical Heritage or the Spanish Ministry of Development.

h) An app for mobile devices will also be developed, so that specific information about these goods will be available on the spot through autonomous bluetooth (beacon) information devices. This would allow the integration of these goods into cultural itineraries, thus ensuring that the results obtained in the project generate a necessary transfer of knowledge to society.

\section{Writing text and graphic conclusions:}

a) Writing interpretive conclusions. Detailed analysis of each of the towers that maintains part of its elevation and the data obtained from the disappeared ones and their location. General conclusions about the development of the constructive techniques of these defensive structures. b) Drawing of new plans and maps. The most upto-date digital cartography will be used in each case study. All these elements will be represented in photogrammetric planimetry at $1: 10$ or 1:20 scale for each of the towers, at a scale of 1: 100 to 1: 500 for their immediate relationship environment, at 1: 5,000 or 1: 10,000 for the study of the landscape in which they are inserted and to scale 1: 500,000 for the territorial frame of the Nasrid kingdom of Granada.

The development of Digital Terrain Models (MDT) will allow a better approximation to the topographic representation of their environments. In order to address these aspects, threedimensional topographic models with $0.10 \mathrm{~m}$ contour lines are being generated (Fig. 4). This digital cartographic base is allowing us a closer study of these towers, their implementation and their relationship with other fortifications, productive structures, historic roads, engineering works, and hydraulic tracings.

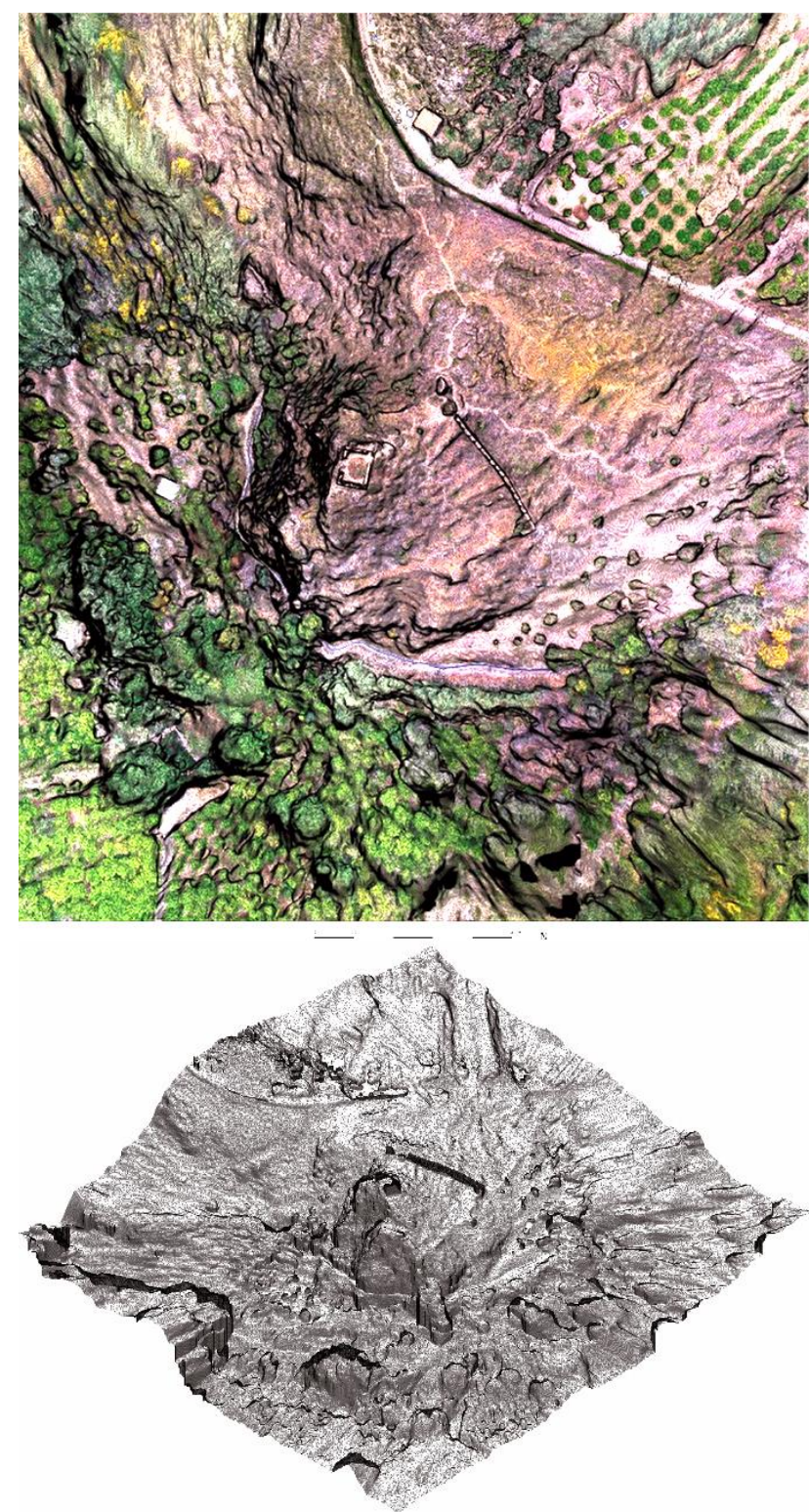

Figure 4. Topographical survey (plan and axonommetric) of the Nasrid tower and fortified enclousure of Lojuela (Murchas, Granada) 
c) Elaboration of a methodological proposal of restauration and systems of repair and reinforcement of the towers. Design of concrete solutions for each typology that could lead to the generation of patents.

10. Presentation and dissemination of this information and transfer to a 3D platform. The results will be published in a collective book and articles in specialized scientific journals through communications at conferences and symposia. The methodological process of dissemination and transmission of this knowledge will also be carried out through the internet through the platforms and GPS viewers. In addition, the dissemination of information in situ through beacon devices significantly increases the interest in their visit resulting in their inclusion in circuits of active tourism (cycling, hiking).

\section{DISCUSSION}

The development of the project will allow a better knowledge about an important historical-cultural stage, which defined the passage from the Middle Ages to the Modern Age. It will allow having complete documentation of a network of more of two hundreds Andalusian military constructions which are not wellknown due to their dispersion and difficult access. The development of Communication Information Technologies to disseminate the graphic documentation developed in this project will allow this information to reach a wide audience without having to move to the places where they are.

It is necessary to undertake a thorough documentation of each of these towers before data continues to be lost. The information generated, in addition to its scientific interest, can be very useful to improve its safeguard, defining the perimeter of protection in each case. At the same time, the results obtained would have relevance for local populations by allowing them to include this Heritage in walking or cycling tours, and in general cultural tourism and ecotourism, one of those with the greatest growth potential.

Given the interest that regional, national, and international institutions have in this research project, special emphasis will be placed on the dissemination and exploitation of results obtained in each tower. They will be uploaded through web applications of the UNESCO Center of Andalusia and the cartographic viewers of the Andalusian Institute of Historical Heritage (IAPH), the Center of Andalusian Studies, the Ministry of Development, the Spanish Society of Construction History, and the Spanish Association of Friends of the Castles or the Center for Historical Studies of Granada and its Kingdom.

\section{CONCLUSIONS}

This wide project is being possible by using new techniques for capturing and mapping detailed physical characteristics of historic structures adapted to process massive data collection of graphic documentation (Almagro Gorbea, 2013, 2004, 1999; Rodríguez-Navarro et al., 2016).

The study of existing information on all this military architecture and the homogenization of all the existing and surveyed plans and maps on a Geographic Information System is allowing the development of registers to record and analyse the same parameters of these constructions. The analysis from the Standing Building Archaeology and from other technical perspectives allow the study of their parallels and influences with other military constructions that have been preserved in geographical areas located in the Iberian Peninsula and in the Maghreb.

The dissemination of the information from the elements studied will be Open Data Source, being totally or partially publishable, establishing different levels of privacy according to the target audience. This would provide adequate filtering of information allowing access to them not only at the scientific and research level, but also enabling its dissemination to the general public and favouring its inclusion in both physical and virtual cultural itineraries.

Thus, the documentation of the assets studied is been filtered through Building Information Modelling and GIS systems, which would allow their inclusion in such databases as the Spatial Data Infrastructure of Spain (IDEE), allowing the analysis and management of all the information of these Cultural Assets.

This will have as a fundamental consequence the dissemination of this important historical heritage. In many cases, these Cultural Assets are difficult to access or are in an excessively poor state of conservation, which makes it impossible to visit them safely. In addition, in the most relevant cases, the provision of autonomous devices for the issuance of information via Bluetooth (beacon) can be planned for on-site access to available information, independently of the internet network, a fact that would reinforce these itineraries and Cultural activities. The new possibilities of reference and location that the current technology offers us, together with the precise knowledge of each fortification and their territory, makes possible the citizens' knowledge of these heritage assets in an integral way, facilitating a Cultural journey characterized by a greater immersion in the landscape and territorial values of the area and having quality information (texts, maps, ancient and current images, cartographic representations at different scales...) through a mobile device.

\section{ACKNOWLEDGEMENTS}

This paper has been written within the framework of the Spanish Proyecto del Plan Nacional $I+D+i$ (Programa Estatal de Fomento de la Investigación Científica y Técnica de Excelencia) entitled 'Las atalayas que defendieron el reino nazari de Granada. Análisis y documentación cientifica (Nazalaya)' ('The watchtowers that defended the nasrid kingdom of Granada. Analysis and scientific survey', HAR2016-79689-P), directed by PhD Luis José García-Pulido and PhD Jonathan Ruiz Jaramillo.

This contribution is also been framed within the projects ' $L a$ construcción de un paisaje: arquitectura de tapial en la Alta Andalucía en el siglo XIII. Estudio y análisis del sistema de torres andalusies en el valle de Segura de la Sierra' ('The building of a Landscape: rammed earth architecture in High Andalusia during the thirteenth century. Analysis of the andalusí tower system in the Segura de la Sierra valley', Proyecto de Investigación Precompetitivo (mod. A) from the Plan Propio de la Universidad de Málaga), and 'Torres medievales y modernas conservadas en Andalucia. Documentación gráfica, análisis científico e interrelaciones' ('Medieval and Modern towers preserved in Andalusia. Graphical survey, scientific anyalisis and interrelations', X Convocatoria de Proyectos de Investigación de la Fundación Pública Andaluza Centro de Estudios Andaluces en la modalidad de proyectos individuales, PRY/259/17). 


\section{REFERENCES}

Acién Almansa, M., 1995. La fortificación en al-Andalus. In: López Guzmán, R. (ed.): La arquitectura del Islam occidental, Barcelona, pp. 29-41.

Almagro Gorbea, A., 1999. Photogrammetry for everybody. In: XVII CIPA International Symposium, Goteborg. 1999, pp. 186190

Almagro Gorbea, A., 2004. Levantamiento arquitectónico. Universidad de Granada, Granada.

Almagro Gorbea, A., 2013. Surveying World Heritage Islamic Monuments in North Africa: Experiences with Simple Photogrammetric Tools and no Previous Planning. ISPRS Annals Photogramm. Remote Sens. Spatial Inf. Sci., II-5/W1, pp. 13-18.

Argüelles Márquez, M., 1995. Sistema de vigilancia y control del Reino Nazarí en Granada. Arqueología y territorio medieval, 2, pp. 83-97.

Arié, R., 1992. El reino nasrí de Granada (1232-1492). MAFPRE, Madrid.

Malpica Cuello, A., 1996. Poblamiento y castillos en Granada. El legado andalusí, Barcelona.

Martín García, M., Bleda Portero, J., Martín Civantos, J. Mª, 1999. Inventario de Arquitectura Militar de la Provincia de Granada (siglos VIII al XVIII). Diputación de Granada, Granada.

Rodríguez-Navarro, P., Gil Piqueras, T. y Verdiani, G., 2016. Drones para el levantamiento arquitectónico. Aplicación para la documentación de las torres del litoral valenciano. In: Actas del Congreso Internacional de Expresión Gráfica Arquitectónica. Serie: Arquitectura y Urbanismo, 71, Alcalá de Henares, pp. 1137-1144.

Tembory Álvarez, J., 1985. Torres almenaras (Costa Occidental) Málaga. Diputación Provincial de Málaga, Instituto de Cultura, Málaga.

Terrasse, H., 1954. Les forteresses de l'Espagne musulmane. Madrid. 